\title{
Eusebius and Hadrian's Founding of Aelia Capitolina IN JERUSALEM
}

\author{
Miriam Ben Zeev Hofman
}

Ben Gurion University of the Negev

\begin{abstract}
From numismatic findings and recent excavations in the Old City of Jerusalem it emerges that the preparatory work on Aelia Capitolina started at the very beginning of Hadrian' reign, most probably in the $120 \mathrm{~s}$, more than a decade before the Bar Kokhba war. The question then arises as how it happened that Eusebius mentions the founding of this colony as a consequence of the war. The answer lies both in the source he depends upon, possibly Ariston of Pella, and also in Eusebius' own conception of Jewish history.
\end{abstract}

Keywords: Bar Kokhba's coins, Jerusalem excavations, Ariston of Pella, Eusebius' view of Jewish history.

The military colony of Aelia Capitolina which Hadrian founded in Jerusalem constitutes a traumatic event and a turning point in Jewish history. The holy city of Jerusalem turned into a pagan site inhabited by Roman soldiers, where idolatrous shrines were built and pagan religious rites were held. Jews were prohibited from entering it.

The meaning of this event has been variously interpreted in modern scholarship, ${ }^{1}$ and its very timing within the context of the Bar Kokhba war has long been debated in view of the conflicting testimonies provided by the extant sources. At the beginning of the third century CE, Cassius Dio records the founding of the colony as preceding the Bar

1 For example, scholars are found who consider it usual Roman praxis and attribute it to technical and logistical considerations (Bowersock 1980, 134-135, 138; Mildenberg 1980, 332-334; Schäfer 1981, 92; Schäfer 1990, 287-288, 296; Schäfer 2003, 147; see also Tameanko 1999, 21; Bieberstein 2007, 143-144; Bazzana 2010,98-99), while others contend that the founding was meant to put an end to Jewish expectations of a Temple by founding a miniature Rome explicitly intended for the settlement of foreign races and foreign religious rites. Aelia Capitolina, Goodman points out, "was to be the last of the Roman colonies which involved the transplantation of a new population to populate the city. Within Hadrian's great policy of urban reconstruction, with the foundation of many cities, Aelia Capitolina is unique in its use of the new colony not to flatter but to suppress the natives" (Goodman 2003, 28-29). Similar views appear in the works of Kindler 2000/2002, 178-179; Speller 2003, 191, and Zissu - Eshel 2016, 388. 
Kochba War ${ }^{2}$ while one century later Eusebius mentions the establishment of the Roman colony after his account of the war. ${ }^{3}$

The implications are clear. If the building of the Roman colony followed the war, as Eusebius claims, then it may be taken as a punitive measure taken by Hadrian, a procedure which often followed Roman victories over rebellious peoples and cities. If, on the other hand, Dio is correct in stating that the founding of the Roman colony preceded the revolt, this means that it may well have been one of the causes which prompted the following war, as Dio suggests.

In the course of the last century, the chronological issue has been settled thanks to numismatic findings. A number of hoards have been found in refuge caves in different places around Judea in the last fifty years, which display coins of Bar Kochba along with coins representing the founding of Aelia Capitolina - which means that the Roman mint started to operate before or during but not after the Bar Kochba War. A special meaning may be attached to the hoard found in the late nineties by Hanan Eshel in the el-Jai Cave in Nahal Mikhmash (Wadi Suweinit), since this was the first hoard of this kind found in a controlled excavation. ${ }^{4}$ The hoard displays four Bar Kochba coins along with two coins representing the founding of Aelia Capitolina, with Hadrian as founder plowing the sulcus primigenius with bull and cow during the ceremony of circumductio aratri to mark out the boundaries of the new colony, accompanied by the legend COL[ONIA] AEL[IA] CAPIT[OLINA] COND[ITA]. These coins, it appears, were brought to the el-Jai Cave by Jewish refugees seeking shelter, possibly toward the end of the war. ${ }^{5}$ The conclusion, therefore, was reached in modern scholarship that, since the Aelia Capitolina coins circulated during the Bar Kochba war, the mint cannot be regarded as a consequence of the war. A more precise date for the founding is now possible thanks to the recent archaeological excavations in the Old City of Jerusalem, where the finds beneath the Cardo in the Western Wall Plaza suggest that the paving works of the Roman colony started at the very beginning of Hadrian's reign. During the preparation works of the Eastern Cardo a quarry, located along the route of the Cardo, was filled up and a massive retaining wall was built inside it along the route of the eastern stylobate. A dump was deposited against this wall and the accumulation was sealed under the mosaic pavement of the Cardo's

2 Cassius Dio 69.12: "At Jerusalem Hadrian founded a city in place of the one which had been razed to the ground, naming it Aelia Capitolina, and on the site of the temple of the god he raised a new temple to Jupiter. This brought on a war of no slight importance nor of brief duration, for the Jews deemed it intolerable that foreign races should be settled in their city and foreign religious rites planted there."

3 HE 4.6.1-4: "The rebellion of the Jews once more progressed in character and extent ... (Rufus, the governor of Judaea) ... destroyed in heaps thousands of men, women, and children, and, under the law of war, enslaved their land. The Jews were at that time led by a certain Bar Chochebas ... a man who was murderous and a bandit ... The war reached its height in the eighteenth year of the reign of Hadrian in Beththera ...; the siege lasted a long time before the rebels were driven to the final destruction by famine and thirst, and the instigator of their madness paid the penalty he deserved. Hadrian then commanded that by a legal decree and ordinances the whole nation should be absolutely prevented from entering the district round Jerusalem, so that not even from a distance could it see its ancestral home. Ariston of Pella tells the story. And thus, when the city came to be bereft of the nation of the Jews, and its ancient inhabitants had completely perished, it was colonized by foreigners, and the Roman city which afterwards arose changed its name, and in honor of the reigning emperor Aelius Hadrian was called Aelia."

4 Eshel-Zissu 2002, 168-172.

5 Eshel 2000, 641-643. 
eastern portico, as well as under the flagstones of the northern of the two streets that extended eastward from the Cardo. All the materials found in the dump - coins, glass, pottery and military bread stamps - have been dated to the first century CE and early second century at the latest. ${ }^{6}$ It was therefore possible to conclude that the eastern thoroughfares of Aelia Capitolina may be dated to the early years of Hadrian's reign, probably in the 120 s, long before his famous visit to the east in 130 and the 'official' founding of Aelia Capitolina. ${ }^{7}$ No doubt, therefore, remains about the correct chronological sequence of the events: ${ }^{8}$ the founding of Aelia Capitolina preceded the Bar Kokhba war by at least a decade. ${ }^{9}$ Nor is this the only sign of the strengthening of the pagan character of Judea attested at the beginning of Hadrian's reign: a similar development is also substantiated by coinage and by the new temples devoted to the emperor cult. ${ }^{10}$

At this point, the question has to be addressed, how it happened that Eusebius regards the founding of Aelia Capitolina not as a cause but as one of the consequences of the Bar Kokhba war. ${ }^{11}$

Certainly it was not an intentional distortion of the historical truth, as a scholar such as Burckhardt, who did not have much esteem for the work of Eusebius, might have assumed in the nineteenth century. ${ }^{12}$ Since Burckhardt's time, a shift has taken place which changed the picture we have of Eusebius, with robust scholarship arguing in support of his integrity ${ }^{13}$ and of his work both as an historian and as a biblical scholar. ${ }^{14}$ Moreover, in our case the chronological misplacement of the founding of Aelia Capitolina may not have been Eusebius' responsibility but that of his source, which Eusebius mentions by name, Ariston of Pella. ${ }^{15}$

The question, therefore, may apply to Ariston. About him and his literary work we know almost nothing. That he must have lived at Pella, one of the cities of the Decapolis, east of the river Jordan, is clear from his very name, but as for the time in which he flourished, nothing certain may be said except for the obvious fact that he lived before Eusebius, probably, according to Bovon and Duffy, in the first half of the second century CE. ${ }^{16}$ Relying on the late testimony of Maximus the Confessor, he is often regarded as the author of the Altercatio Iasonis et Papisci (Dialogue of Jason and Papiscus), an early, if not the very first, example of polemical literature against the Jews, ${ }^{17}$ which was

6 See Di Segni - Weksler-Bdolah 2012, 24*, 26*, 29*.

7 Di Segni - Weksler-Bdolah 2012, 21*-31*; Weksler-Bdolah et al. 2012, 47; Weksler-Bdolah Rosenthal-Heginbottom 2014, 48-49.

8 Pace Mantel 1967/1968, 240-242.

9 See Ben Zeev 2018, 84-107.

10 See Ben Zeev 2018, 98-99.

11 See above, note 3.

12 Entirely negative views appear all over Burckhardt' work. See his The Age of Constantine the Great translated by Hadas (1949), 190, 200, 241, 249-250, 272, 275, 281-282, 285-288, 302.

13 Hollerich 2013, 312.

14 See Singh 2015, 29 and 129, note 1. Adler (1992, 479), too, remarks that the personality of Eusebius that is revealed throughout his work "is that of a writer acutely aware of the difficulties attending the use of historical documents."

15 HE 4.6.3: "Such is the account of Aristo of Pella."

16 Bovon - Duffy 2012, 459, note 9.

17 Concerning the beginning of the Adversus Iudaeos literature, Stroumsa $(1996,18)$ observes that polemics was the literary reflection of the conflictual relationship between competing religious groups, but 
relatively popular in the second, third, and fourth centuries. ${ }^{18}$ This attribution, however, is not certain, ${ }^{19}$ and, consequently, it is impossible to know if Eusebius found Ariston's passage concerning the Bar Kokhba in the Altercatio or in another work written by Ariston, perhaps, as has been argued, a historical one,${ }^{20}$ whether directly or through an unidentified intermediary. ${ }^{21}$

Certainly, Ariston's perspective is a Christian one. The possibility that he was a Jew, which has been suggested, ${ }^{22}$ may be safely rejected, since his account of the Bar Kokhba war has a marked anti-Jewish character. The leader of the revolt is called "a man who was murderous and a bandit," "instigator" of the Jews" "madness," and, moreover, it is stated that he finally "paid the penalty he deserved," all expressions which hardly suit a Jewish perspective. In spite of the fact that he lived at Pella, which is not far from Judea, Ariston must not have had firsthand detailed knowledge of what transpired in Judea before, during and after the Bar Kokhba war, and possibly mentioned the events according to his own understanding, regarding it as plausible that the Roman colony was devised by Hadrian as a punitive measure after the Jewish rebellion was quelled.

However, one cannot be certain that the mention of the founding of Aelia Capitolina as a consequence of the revolt may be attributed to Ariston and not to Eusebius himself. In fact, Eusebius mentions Ariston as his source not at the end of his account of the Bar Kokhba war but rather at some point in the middle, after mentioning the rescript of Hadrian which prevented the Jews from entering the district around Jerusalem. At this point he states that "Ariston of Pella tells the story," and then continues with two more pieces of information, namely, that the city was colonized by foreigners and that the Roman city which afterwards arose changed its name, and in honor of the reigning emperor Aelius Hadrian was called Aelia. ${ }^{23}$ While the mention of Ariston in the middle of the account may perhaps be regarded as a literary device, it is also not impossible that Eusebius had one or more additional sources (perhaps oral ones?) and that he inserted their testimony at what he deemed to be the best place, at the end of the account where the consequences of the revolt are mentioned.

This should come as no surprise, since the theme of the misfortunes of the Jewish people is a recurrent theme in Eusebius' work. His main interest, of course, lay in Christianity, as he states in the preface of his Historia Ecclesiastica, ${ }^{24}$ but, as Droge aptly

it served multiple purposes. It was not intended only, or even mainly, to convince and convert, but also to strengthen the faith, or the self-confidence, of those who had already converted. On Jewish-Christian polemics in the first centuries CE see the works cited by Kofsky 1996, 65, note 19.

18 Bovon - Duffy 2012, 459-460, against the view of Millar and Vermes (cf. Schürer 1973, 38).

19 Carriker $(2003,191)$ argues that the connection between Ariston of Pella and the Altercatio is quite tenuous. Maximus the Confessor, who mentions Ariston as the author of the Altercatio, lived as late as the seventh century CE; earlier witnesses report obviously inaccurate authorship; authors such as Celsus, Origen and Jerome fail to mention the author of the Altercatio, and, finally, Clement of Alexandria attributes it to St. Luke.

20 See Jacoby's suggestion quoted by Carriker (2003, 192, note 52). Bruns (1973, 288), too, observes that Aristo may well have written more than one work.

${ }^{21}$ From Eusebius' silence about Ariston's literary work, Bovon - Duffy $(2012,460)$ infer that he may have had some kind of reservation about it.

22 See Carriker 2003, 192.

23 HE 4.6.3-4.

24 HE 1.1.1: "It is my purpose to write an account of the successions of the holy apostles, as well as of the times which have elapsed from the days of our Savior to our own; and to relate the many important events 
points out, even a casual reading reveals that this work is much more than this modest statement would suggest. In addition to attempting to describe chronologically 'what actually happened', Eusebius also endeavored to explain what Christianity was and to place it within the general history of mankind. ${ }^{25}$ The exact proceedings of the Roman ${ }^{26}$ and of the Jewish ${ }^{27}$ histories was beyond the purpose of his work, but he was interested in their theological meaning. In the case of Jewish history, he focused on those events which could be regarded as a divine punishment of the Jews for the crucifixion of Jesus. ${ }^{28}$ As Hollerich observes, Eusebius' apologetic conception of history led him to incorporate the present into an ongoing, biblically grounded demonstratio evangelica. Judging the events of his time from a religious perspective, he used secular history for religious purposes, so that history and politics were assessed from a religious standpoint. ${ }^{29}$

At the beginning of his Historia Ecclesiastica, Eusebius overtly states that he intends "to recount the misfortunes which came upon the whole Jewish nation because of their plot against our Savior." 30 Such misfortunes were duly deserved by the Jews, he explains, not only for their "plot against our Savior" but also for their later stubborn failure to recognize him as their Messiah. ${ }^{31}$ Therefore they were punished by the loss of the great priesthood, of the prophecy, of the kingship and then of the Temple ${ }^{32}-$ where $^{2}$ events are assembled, not only those which followed but also those which preceded the time of Jesus. Eusebius' negative attitude is well explained by Strouma. When Christianity was still a religio illicita, and early Christian intellectuals were striving for intellectual respectability, they were the first to develop a coherent argument about the need for religious tolerance, and hence pluralism. In the fourth century, however, the situation had changed. The conversion of the emperor ${ }^{33}$ brought with it the disappearance of religious pluralism, so that in the fourth and fifth-century we find a de-legitimation

which are said to have occurred in the history of the Church; and to mention those who have governed and presided over the Church in the most prominent parishes, and those who in each generation have proclaimed the divine word either orally or in writing."

25 Droge 1992, 492.

26 Grant observes, for example, that what Eusebius wrote about Roman emperors reveals "how inadequate his picture of them was. He knew nothing of their lives, policies, struggles. In most instances he simply repeated the transient judgements of prior apologists" (Grant 1992, 663-664).

27 Grant $(1979,81)$ observes that for events in Jewish history which took place after 70 CE, Eusebius's sources are 'inadequate, distasteful, or both.'

28 Grant 1992, 661, 663-664.

29 See Hollerich 1990, 324.

30 HE 1.1.3. This opening statement, Irshai $(2012,804)$ points out, can and should be regarded as an understatement, because the Jews, or matters concerning Jews or Judaism, seem to occupy a substantial portion of five out of the ten books of his Historia Ecclesiastica. Eusebius seems to have been one of the first ecclesiastic authors to call the Jews kurioktonoi, murderers of the Lord (see Inowlocki 2006, 134). According to Grant (1980, 97, note 1), the notion of Jewish 'plots' is apparently derived from the Acts of the Apostles.

31 See Fredriksen - Irshai 2006, 982 and Attridge - Hata 1992, 42, who observe that, for Eusebius, the rejection of Christian claims for Jesus by the people of Israel meant the end of their history as God's chosen.

32 See Inowlocki 2006, 133. On p. 134, she aptly notes that according to Josephus, the argument that the miseries of the Jews proved the error of their cult had already been used by Apion (C. Ap. 2.125): "A clear proof, according to him (Apion), that our laws are unjust and our religious ceremonies erroneous, is that we are not masters of an empire, but rather the slaves, first of one nation, then of another, and that calamity has more than once befallen our city." On Eusebius' dealings with the fate of the Jews, see also Grant 1980, 97-113.

33 See Barnes 1981. 
of religious pluralism, and in the context of this revolution in religiosity we must understand the radicalization of anti-Jewish attitudes. ${ }^{34}$ In the fourth century, the Christian texts which survive show a growing propensity to identify contemporary Jews with the killers of Christ, and to perceive them in sharp contradistinction to both the ancient Hebrews and their spiritual heirs, the Christians, namely, the verus Israel. ${ }^{35}$ Eusebius subtly distinguishes the Jews from the ancient Hebrews, who had excelled in piety, charity and all the virtues and who are identified as ancestors of the Christians themselves, in fact, as Christian patriarchs themselves. ${ }^{36}$ For Eusebius, the decline of the Hebrews started with the Law introduced by Moses and its peculiar precepts, which, anyway, Eusebius regards as applying only to the people living in Judea. ${ }^{37}$ In addition to Jews' alleged crucifixion of Jesus, ${ }^{38}$ Eusebius accuses the Jews of additional crimes: to have misinterpreted the Scriptures, to have failed to recognize that the prophecies were fulfilled in Christ; ${ }^{39}$ and to have played a role in the persecutions against the Christians. ${ }^{40}$ Moreover, the Jews are accused of having dared to rebel against the Roman Empire, an Empire which had a special blessed role, having being chosen by God to enable the spread of Christianity in the world. ${ }^{41}$ For all these reasons, the Jews were duly pun-

34 Ulrich $(1999,146)$ recognizes no anti-Jewish attitudes. According to him, the fact that Eusebius leaves open the possibility for the Jews to enter the kingdom of God if they espouse Christianity means that Eusebius was tolerant towards Jews and Judaism from a theological view point. Jacobs $(2001,559)$ points out that Ulrich "softens Eusebius's theological presentation of Jews; he admits that the chastisement of the Jews looms large in Eusebius's writings, but insists that he takes no 'malicious joy' in recounting their miseries (p. 139-140) (as compared, for instance, with Chrysostom)." According to Van den Hoek, Ulrich's many "apologetic" gestures in defense of Eusebius remain rather unconvincing when stating at various levels that although Eusebius appears to be hostile he is not. "In my view, it is more realistic to say that if he appears to be, he is - Eusebius' use of slanderous language is rather revealing in this respect" (Van den Hoek 2000, 438).

35 Stroumsa 1996, 18-21.

36 On the terminology used by Eusebius concerning the Jews, see Ulrich 1999, 57-131. See also Droge 1992, 499, 502; Kofsky 1996, 78; Stroumsa 1996, 8; Inowlocki 2006, 109-131; Inowlocki 2007, 255; Iricinschi 2011, 69-86.

37 Kofsky 1996, 81. Among the historical Jewish people, Eusebius distinguishes between those who lived according to the literal meaning of the laws, and those who attained virtues and led virtuous lives, the criteria for 'Hebrewness' being loyalty to scripture and covenant, erudition and learned culture (see Ulrich 1999, 68). Such were for Eusebius not only the patriarchs but also Jewish philosophers, such as Aristobulus, the Essenes, Philo, and Josephus, who are regarded by Eusebius as followers of the ancient Hebrews like the prophets who preceded them (Kofsky 1996, 75-76). This may be the reason why Eusebius makes extensive use of their works. In a peculiar way, though. Inowlocki $(2004,49)$ observes that by examining the material from the Legatio used by Eusebius one may learn something about his working method: how faithful he can be to a text when it adheres to his purposes, and how manipulative he can be when he wishes to use a text for his own theological and historical views which do not correspond to the ideology of the original author. Paraphrasing, summarizing, citing faithfully or ignoring some parts of the text undeniably constituted important apologetic tools which enables Eusebius to build his own picture.

38 HE 1.1.2.

39 See Inowlocki 2006, 135; Hollerich 1992, 598; Hollerich 2013, 643-645.

40 On this subject, see Inowlocki 2006, 135.

${ }^{41}$ On the role of the Pax Romana in aiding the evangelizing of the empire, see Hollerich 1990, 314, and 315 , note 30 , on the divine punishment of the Jews through the agency of the Roman emperors, and 323, note 61 on Vespasian and Hadrian as God's agents executing God's orders and purposes. For a discussion of the extent of Eusebius' endorsement both to Constantine and to the Roman Empire, see Maraval 2011, 75-145; Hollerich 1990, 309-325; Hazel 2016, 171-204. 
ished in the course of their history. Some pertinent examples are provided by Barnes. ${ }^{42}$ Eusebius interprets the policy of Caligula against the Jews as God's vengeance for their protestation before Pilate that they had no king but Caesar, ${ }^{43}$ and emphasizes the riots, the wars and the internecine strife that characterize life in Judaea from the reign of Claudius onwards, until a Roman army captured Jerusalem. ${ }^{44}$ Eusebius also states that Josephus shows that the death of Herod Agrippa in 44 was a consequence of his execution of James, the brother of John, and adds that even some Jews admitted that the stoning of James, the brother of Jesus, was a cause of the siege of Jerusalem. ${ }^{45} \mathrm{Ad}-$ ditional punishment visited Jerusalem and the rest of Judaea when the Christian church of Jerusalem deserted it and moved to Pella beyond the Jordan, ${ }^{46}$ and then came the utter disaster foretold both by prophets and by Jesus himself. Thousands of Jews were slaughtered, and Judaea was laid waste. ${ }^{47}$ Quoting Josephus' description of the famine inside the besieged Jerusalem, Eusebius adds that this was "the reward of the Jews for their wickedness and impiety towards the Christ of God". ${ }^{48}$ The misfortunes of the Jews are put in sharp contrast with the success of the Christian Church, as Eusebius points out when introducing his account of the Diaspora uprisings in Trajan's days:

The teaching and the Church of our Savior flourished greatly and made progress from day to day; but the calamities of the Jews increased, and they underwent a constant succession of evils. In the eighteenth year of Trajan's reign there was another disturbance of the Jews, through which a great multitude of them perished. ${ }^{49}$

The same patterns are discernable in the account of the Bar Kokhba war, where Eusebius stresses the misfortune in which the Jews incurred in Hadrian's days, their final destruction by famine and thirst, the building of a pagan colony in Jerusalem, and Hadrian's decree according to which "the whole nation (of the Jews) should be absolutely prevented from entering from thenceforth even the district round Jerusalem, so that it could not even see from a distance its ancestral home." ${ }^{50}$

Whether relying on Ariston, on another source or on his own understanding, Eusebius' chronological misplacement is not accidental. It fits the pattern: Jewish crimes righteous punishment, which forms a basic and consistent motif of his historical outlook. According to this perspective, for Eusebius the consequences of the Bar Kokhba war constituted one more manifestation of divine intervention in human affairs. ${ }^{51}$

42 Barnes 1981, 135-136.

43 HE 2.4-6.

HE 2.19-23, 26; 3.5-8.

45 HE 2.10.

HE 3.5.3.

HE 3.5-7.

HE 7.1. See Grant 1979, 69; Grant 1980, 103-111; Mendels 2001, 295-303; Hollerich 2013, 599.

HE 4.2.1.

HE 4.6.1-4.

51 On the influence of Origen on Eusebius regarding the fate of the Jews, see Grant 1979, 78. See also Kannengiesser 1992, 435-466 and Ulrich 1992, 543-562. On the role of the Jews in history, see also Ulrich 1999, 146-154. 


\section{BIBLIOGRAPHY}

Adler, W. (1992), Eusebius' Chronicle and Its Legacy, in: H. W. Attridge, G. Hata (eds.), Eusebius, Christianity, and Judaism, (Studia Post-Biblica 42), Leiden: 467-491.

Attridge, H. W., Hata, G. (1992), Introduction, in: H. W. Attridge, G. Hata (eds.), Eusebius, Christianity, and Judaism, (Studia Post-Biblica 42), Leiden: 27-49.

Barnes, T. D. (1981), Constantine and Eusebius, Cambridge, MA-London.

Bazzana, G. B. (2010), The Bar Kokhba Revolt and Hadrian's Religious Policy, in: M. Rizzi (ed.), Hadrian and the Christians, Berlin-New York: 85-109.

Ben Zeev, M. (2018), New Insights into Roman Policy in Judea on the Eve of the Bar Kokhba Revolt, Journal for the Study of Judaism 49: 84-107.

Bieberstein, K. (2007), Aelia Capitolina, in: Z. Kafafi, R. Schick (eds.), Jerusalem before Islam, Oxford: $134-168$.

Birley, A. R. (1997), Hadrian: The Restless Emperor, London.

Bovon, F., Duffy, J. M. (2012), A New Greek Fragment from Ariston of Pella's Dialogue of Jason and Papiscus, Harvard Theological Review 105: 457-465.

Bowersock, G. W. (1980), A Roman Perspective on the Bar Kochba War, in: W. Scott Green (ed.), Approaches to Ancient Judaism, vol. 2, Missoula, MT: 131-141.

Bruns, J. E. (1973), The Altercatio Iasonis et Papisci, Philo, and Anastasius the Sinaite, Theological Studies 34: 286-294.

Burckhardt, J. (1949), The Age of Constantine the Great, translated by Moses Hadas, New York (Trans. of Die Zeit Konstantins des Grossen, Leipzig 1880).

Carriker, A. J. (2003), The Library of Eusebius of Caesarea, (Supplements to Vigiliae Christianae 67), Leiden.

Di Segni, L. (2014), Epiphanius and the Date of Foundation of Aelia Capitolina, Liber Annuus 64: $441-451$.

Di Segni, L., Weksler-Bdolah, Sh. (2012), Three Military Bread Stamps from the Western Wall Plaza Excavations, Jerusalem, 'Atiqot 70: 21-31.

Droge, A. J. (1992), The Apologetic Dimensions of the Ecclesiastical History, in: H. W. Attridge, G.Hata (eds.), Eusebius, Christianity, and Judaism, (Studia Post-Biblica 42), Leiden: 492-509.

Eck, W. (2005), Ehret den Kaiser: Bögen und Tore als Ehrenmonumente in der Provinz Iudaea, in: M. Perani (ed.), The Words of a Wise Man's Mouth Are Gracious (Qoh 10:12): Festschrift for G. Stemberger on the Occasion of his 65 Birthday, Berlin: 153-165.

Eliav, Y. Z. (1997), Hadrian's Actions in the Jerusalem Temple Mount according to Cassius Dio and Xiphilini Manus, Jewish Studies Quarterly 4: 125-144.

Eliav, Y. Z. (2003), The Urban Layout of Aelia Capitolina - a New View from the Perspective of the Temple Mount, in: P. Schäfer (ed.), The Bar Kokhba War Reconsidered: New Perspectives on the Second Jewish Revolt against Rome, Tübingen: 241-277.

Eliav, Y. Z. (2005), God's Mountain: The Temple Mount in Time, Place and Memory, Baltimore.

Eshel, H. (1997), Aelia Capitolina: Jerusalem No More, Biblical Archaeological Review 23 (6): $46-48,73$.

Eshel, H. (2000), The Date of the Founding of Aelia Capitolina, in: L. H. Schiffman et al. (eds.), The Dead Sea Scrolls Fifty Years after Their Discovery, Jerusalem: 637-643.

Eshel, H., Zissu, B. (2002), Coins from the el-Jai Cave in Nahal Mikhmash (Wadi Suweinit), Israel Numismatic Journal 14: 168-172.

Fredriksen, P., Irshai, O. (2006), Christian Anti-Judaism: Polemics and Policies, in: S. Katz (ed.), Cambridge History of Judaism, vol. 4, Cambridge: 977-1034.

Goodman, M. (2003), Trajan and the Origins of the Bar-Kokhba War, in: P. Schäfer (ed.), The Bar Kochba War Reconsidered: New Perspectives on the Second Jewish Revolt against Rome, Tübingen: 23-29. 
Grant, R. M. (1979), Eusebius, Josephus and the Fate of the Jews, Society of Biblical Literature Seminar Papers 2: 69-86.

Grant, R. M. (1980), Eusebius as Church Historian, Oxford.

Grant, R. M. (1992), Eusebius and Imperial Propaganda, in: H. W. Attridge, G. Hata (eds.), Eusebius, Christianity, and Judaism, (Studia Post-Biblica 42), Leiden: 658-683.

Hazel, J. (2016), The Demonic in the Political Thought of Eusebius of Caesarea, Oxford.

Hollerich, M. J. (1990), Religion and Politics in the Writings of Eusebius: Reassessing the First 'Court Theologian,' Church History 59: 309-325.

Hollerich, M. J. (1992), Eusebius as a Polemical Interpreter of Scripture, in: H. W. Attridge, G. Hata (eds.), Eusebius, Christianity, and Judaism, (Studia Post-Biblica 42), Leiden: 585-615.

Hollerich, M. (2013), Eusebius, in: J. C. Paget, J. Schaper (eds.), New Cambridge History of the Bible, vol. 1: From the Beginnings to 600, Cambridge: 629-652.

Inowlocki, S. (2004), The Reception of Philo's "Legatio ad Gaium" in Eusebius of Caesarea's Works, Studia Philonica Annual 16: 30-49.

Inowlocki, S. (2006), Eusebius and the Jewish Authors: His Citation Technique in an Apologetic Context, Leiden-Boston.

Inowlocki, S (2007), Eusebius' Appropriation of Moses in an Apologetic Context, in: A. Graupner, M. Wolter (eds.), Moses in Biblical and Extra-Biblical Traditions, Berlin-New York: 241-255.

Iricinschi, E. (2011), Good Hebrew, Bad Hebrew: Christians as Triton Genos in Eusebius' Apologetic Writings, in: S. Inowlocki et al. (eds.), Reconsidering Eusebius: Collected Papers on Literary, Historical and Theological Issues, Leiden-Boston: 69-86.

Irshai, O. (2012), Jews and Judaism in Early Church Historiography: The Case of Eusebius of Caesarea (Preliminary Observations and Examples), in: R. Bonfil et al. (eds.), Jews in Byzantium: Dialectics of Minority and Majority Cultures, Leiden-Boston: 799-828.

Jacobs, A. S. (2001), rev. of J. Ulrich, Euseb von Caesarea und die Juden. Studien zur Rolle der Juden in der Theologie des Eusebius von Caesarea, Berlin-New York 1999, Church History 70: 558-560.

Kannengiesser, Ch. (1992), Eusebius of Caesarea, Origenist, in: H. W. Attridge, G. Hata (eds.), Eusebius, Christianity, and Judaism, (Studia Post-Biblica 42), Leiden: 435-466.

Kindler, A. (1961), The Coins of Tiberias, Tiberias.

Kindler A. (2000/2002), Was Aelia Capitolina Founded before or after the Outbreak of the Bar Kokhba War? A Numismatic Evidence, Israel Numismatic Journal 14: 176-179.

Kofsky, A. (1996), Eusebius of Caesarea and the Christian-Jewish Polemic, in: O. Limor, G. Stroumsa (eds.), Contra Iudaeos: Ancient and Medieval Polemics between Christians and Jews, (Texts and Studies in Medieval and Early Modern Judaism 10), Tübingen: 59-83.

Magness, J. (2011), Aelia Capitolina: A Review of Some Current Debates about Hadrianic Jerusalem, in: H. Galor, G. Avni (eds.), Unearthing Jerusalem: 150 Years of Archeaological Research in the Holy City, Winona Lake, IN: 313-324.

Mantel, H. (1967/1968), The Causes of the Bar Kokhba Revolt, Jewish Quarterly Review 68: 224-242; 274-296.

Maraval, P. (2011), Eusèbe de Césarée, la théologie politique de l'empire chrétien: louanges de Constantin (Triakontaétérikos), Paris.

Mendels, D. (2001), The Use of Josephus by Eusebius in His 'Ecclesiastical History,' in: J. U. Kalms (ed.), Internationales Josephus-Kolloquium Amsterdam 2000, Münster: 295-303.

Mildenberg, L. (1980), Bar Kokhba Coins and Documents, Harvard Studies in Classical Philology 84: 311-335.

Mor, M. (2016), The Second Jewish Revolt: The Bar Kokhba War, 132-136 CE, Leiden-Boston. Murphy-O'Connor, J. (1994), The Location of the Capitol in Aelia Capitolina, Revue Biblique 101: 407-415.

Murphy-O'Connor, J. (1994), The Location of the Capitol in Aelia Capitolina, Revue Biblique 101: 407-415. 
Pucci Ben Zeev, M. (2005), Diaspora Judaism in Turmoil, 116/117 CE: Ancient Sources and Modern Insights, Leuven-Dudley, MA.

Schäfer, P. (1981), The Causes of the Bar Kokhba Revolt, in: J. J. Petuchowski, E. Fleischer (eds.), Studies in Aggadah, Targum and Jewish Liturgy in Memory of Joseph Heinemann, Jerusalem: 74-94.

Schäfer, P. (1990), Hadrian's Policy in Judaea and the Bar-Kokhba Revolt: A Reassessment, in: Ph. R. Davies, R. T. White (eds.), A Tribute to G. Vermes: Essays on Jewish and Christian Literature and History, (Journal for the Study of the Old Testament Supplement Series 100), Sheffield: 281-303.

Schäfer, P. (2003), The History of the Jews in the Greco-Roman World: The Jews of Palestine from Alexander the Great to the Arab Conquest, London.

Schürer, E. (1973), The History of the Jewish People in the Age of Jesus Christ (175 B.C.-A.D. 135), eds. G. Vermes, F. Millar, vol. 1, Edinburgh.

Singh, D. (2015), Eusebius as Political Theologian: The Legend Continues, Harvard Theological Review 108: 129-154.

Speller, E. (2003), Following Hadrian: A Second-Century Journey through the Roman Empire, Oxford.

Stroumsa, G. G. (1996), From Anti-Judaism to Antisemitism in Early Christianity?, in: O. Limor, G. Stroumsa (eds.), Contra Iudaeos: Ancient and Medieval Polemics between Christians and Jews, Tübingen: 1-26.

Tameanko, M. (1999), Hadrian and the Jews: A Relationship Shown on Ancient Coins, The Shekel 32 (6): $17-25$.

Ulrich, E. (1992), The Old Testament Text of Eusebius: The Heritage of Origen, in: H. W. Attridge, G. Hata (eds.), Eusebius, Christianity, and Judaism, (Studia Post-Biblica 42), Leiden: 543-562.

Ulrich, J. (1999), Euseb von Caesarea und die Juden: Studien zur Rolle der Juden in der Theologie des Eusebius von Caesarea, Berlin.

Van den Hoek, A. (2000), rev. of J. Ulrich, Euseb von Caesarea und die Juden. Studien zur Rolle der Juden in der Theologie des Eusebius von Caesarea, Berlin-New York 1999, Vigiliae Christianae 54: 435-438.

Weksler-Bdolah, Sh., Onn, A. (2017), Colonnaded Streets in 'Aelia Capitolina': New Evidence from Eastern Cardo, in: G. Avni, G. D. Stiebel (eds.), Roman Jerusalem: A New Old City, (JRA Supplementary Series 105), Portsmouth, RI: 11-22.

Weksler-Bdolah, Sh., Onn, A., Kisilevitz, Sh., Ouahnouna, B. (2012), Layers of Ancient Jerusalem, Biblical Archaeology Review 38 (1): 37-47.

Weksler-Bdolah Sh., Rosenthal-Heginbottom, R. (2014), Two Aspects of the Transformation of Jerusalem into the Roman Colony of Aelia Capitolina, in: G. C. Bottini et al. (eds.), Knowledge and Wisdom: Archaeological and Historical Essays in Honor of Leah Di Segni, Milano: 43-61.

Zissu, B., Eshel, H. (2016), Religious Aspects of the Bar Kokhba Revolt: The Founding of Aelia Capitolina on the Ruins of Jerusalem, in: K. Ulanowski (ed.), The Religious Aspects of War in the Ancient Near East, Greece and Rome, (Culture and History of the Ancient Near East 84), LeidenBoston: 387-405. 